7. Скабелина Л. А.: Психологические аспекты адвокатской деятельностиМосква. - 2012. - С. 68.

8. Чуфаровский Ю.В.: Юридическая психология. - М.: Проспект, - 2010. C. 115 .

\title{
ОСОЗНАНИЕ СОДЕЯННОГО НЕСОВЕРШЕННОЛЕТНИМИ ОБВИНЯЕМЫМИ, КАК ОДИН ИЗ ВИДОВ ПРОЯВЛЕНИЯ ДЕФЕКТОВ ПРАВОВОЙ СОЦИАЛИЗАЦИИ \\ Церекидзе Я.В., Шуванов И.Б.
}

Социализация личности - одна из тех проблем познания, актуальность изучения которой не ослабевает с течением времени. Если же говорить о современном российском обществе, которое находится на данный момент на этапе трансформации, необходимость разработки проблемы социализации только усиливается.

Исходя из вышеизложенного, следует сказать, что вопросом социализации личности посвящено большое количество работ отечественных и зарубежных философов, социологов и психологов, таких как: Ст.Холл, А.Гезел, З.Фрейд, В.Скиннер, А.Бандура, Л.Колберг, Э.Эриксон, А.Оллпорт, А.В.Петровский, Ж.Пиаже и др.

В следствии такой научной заинтересованности социализацией личности, сформировалось множество подходов и теорий. Обобщая данные подходы к определению понятия « социализация», можно отметить, что данный процесс рассматривается как активное усвоение индивидом социального опыта, социальных функций, а также это процесс внутреннего индивидуального развития личности, который направлен на социальное самоопределение через осмысление полученного опыта, дальнейшее его преобразование и возобновление.

Иными словами, социализация личности - это двусторонний процесс усвоения индивидом социального опыта того общества, к которому он принадлежит, с одной стороны, и активного воспроизводства и наращивания систем социальных связей и отношений, в которых он развивается, - с другой.

Как известно, в процессе социализации личность, усваивая социальный опыт общества, в котором находиться, усваивает и нормы поведения этого общества, иначе говоря, усваивает социальные нормы, которые, в свою очередь, подразделяются на мифы, ритуалы, обычаи, религиозные нормы, правовые нормы и моральные нормы.

Правовые нормы тесно взаимосвязаны с другими социальными нормами. Правовые и моральные нормы распространяются на все общество. Они имеют единый объект регулирования - общественные отношения.

От других норм ее отличают, во-первых, всеобщий характер, своего рода обезличенность, распространение на всех участников общественных отношений, независимо от их воли и желания. Во-вторых, правовая норма, в отличие, например, от морали, призвана регулировать внешнее поведение людей, обращена к их воле и сознанию в расчете на определенный поступок. В- 
третьих, правовая норма отличается от других субъектом своего подтверждения в качестве таковой.

Правовые нормы регулируют правоисполнительное поведение личности, которое формируется в результате ее правовой социализации.

Правовая социализация личности - включение в ценностно-нормативную систему личности ценностей, охраняемых правом; овладение личностью правомерными способами поведения, формирование у нее чувства социальной ответственности и солидарности с правом (Еникеев М.И.)

Формирование у личности в процессе правовой социализации законопослушного поведения, безусловно, является наиболее желательной целью. Однако в процессе правовой социализации возможны социальнонегативные отклонения - от совершения незначительных правонарушений до преступлений. Дефектность правовой социализации может проявляться: в недооценке ценности права (правовой негативизм); в безответственном, легкомысленном отношении к требованиям закона (правовой инфантилизм); в активном неприятии норм права (правовой нигилизм); в сознательном или несознательном преступном поведении.

Анализ литературы показал, что из всех дефектов правовой социализации личности наиболее социально опасны дефекты социализации в семье, усиливая криминогенный потенциал несовершеннолетних

Из всех вышеперечисленных проявлений дефектности социализации нас больше интересует сознательное или несознательное преступное поведение, так как в основе данного проявления лежит осознание содеянного преступления.

Таким образом, высший уровень правовой социализации - поведение личности на основе правосолидарных установок - привычное правоисполнительное поведение как устойчивая особенность нравственной личности. При этом нормы права соблюдаются не из страха наказания и даже не из чувства солидарности с правом, а по настоятельной нравственной потребности совершать только правомерные действия - жить достойно. Несовершеннолетние правонарушители должны не только понимать, что в обществе существуют определенные законы, но и соотнести их с собой осознать, что именно эти законы значат для них, установить границы дозволенного и запрещенного. Если подследственный не мог в полной мере осознавать фактическое содержание своего поведения или способность к волевой регуляции у него была деформирована, то он не может в полной мере отвечать за свои поступки. Юридической оценке подвергаются только сознательные действия субъекта, которыми он может управлять. Проблема осознания своих действий и способности руководить ими является стержневой проблемой судебно-психологической экспертизы несовершеннолетних и малолетних правонарушителей.

Полное осознание человеком значения своих действий включает в себя: а) правильное понимание объективного содержания собственного поведения; б) понимание целей совершаемых действий; в) предвидение результатов своих деяний; г) оценка своих действий с точки зрения действующих моральных и правовых норм. Способность руководить своими действиями выражается в 
свободном выборе, как целей, так и способов их достижения. Выбор способа неразрывно связан с мотивами поведения.

Дефектность правовой социализации проявляется в сознательном или несознательном преступном поведении. Осознавая содеянное преступление, можно говорить о том, что несовершеннолетний не усвоил правовые нормы, которые регулируют правоисполнительное поведение личности, формирующееся в результате ее правовой социализации. Следовательно, осознание содеянного - есть дефект правовой социализации.

\section{Литература:}

1. Прикладная юридическая психология /Под ред. А.М. Столяренко. М.: ЮНИТИ-ДАНА, 2014.

2. Еникеев М.И. Юридическая психология.- СПб.: Питер, 2013.

3. Андреева Г.М. Социальная психология. Учебник для высших учебных заведении. - М.: Аспект Пресс, 2011. 